\title{
IgA autoantibodies against native myelin basic protein in a patient with MS
}

Heike Schumacher, Nina K. Wenke, PhD, Jakob Kreye, MD, Markus Höltje, PhD, Katrin Marcus, PhD, Caroline May, PhD,* and Harald Prüss, MD*

Neurol Neuroimmunol Neuroinflamm 2019;6:e569. doi:10.1212/NXI.0000000000000569

Myelin basic protein (MBP) is one of the most abundant proteins in the human brain. Active immunization with MBP induces experimental autoimmune encephalomyelitis, and anti-MBP antibodies have been repeatedly described in MS. ${ }^{1}$ However, its role in MS pathogenesis or prediction of disease progression is still unclear. ${ }^{2,3}$ Previous studies utilized enzyme-linked immunosorbent assay or immunoblot assays with linear epitopes of MBP, thus potentially overlooking autoantibodies that bind to MBP's natural conformation. These initial studies also included antibodies against another myelin protein, myelin oligodendrocyte glycoprotein (MOG). As happened for MBP, conflicting results stimulated the discussion of whether MOG antibodies contribute to MS pathogenesis. ${ }^{2,3}$ More recent work demonstrated that there are presumably pathogenic MOG antibodies defining the new entity of MOG antibody-associated disease; ${ }^{4}$ however, they bind to conformational MOG only.

Here we report on a patient with MS with immunotherapy-responsive severe cognitive impairment having high-level immunoglobulin A ( $\operatorname{IgA}$ ) autoantibodies against conformational $\mathrm{MBP}$, suggesting the possibility of myelin-directed humoral autoimmunity beyond MOG.

\section{Case report}

A 54-year-old woman with a 20-year history of relapsing-remitting MS (Expanded Disability Status Scale 3.5) was admitted for a suspected relapse with subacute-onset rapidly progressing cognitive decline, presenting with dementia and echolalia. Apart from unsteady gait, double vision, and lack of coordination, cerebellar and motor signs were relatively spared, and the MRI showed new lesions (figure, A and B). Previous treatments included mitoxantrone (19 cycles, cumulative dose $137 \mathrm{mg} / \mathrm{m}^{2}$ ) and beta-1a interferon (3 years of $44 \mu \mathrm{g} 3$ times per week). Given the unusual predominance of cognitive symptoms with rapid deterioration from 18 to $14 / 30$ points in Mini-Mental State Examination, secondary autoimmune encephalitis was considered. Indirect immunofluorescence revealed high titers of brain-reactive IgA antibodies (serum 1: 3,200, CSF 1:32, antibody index 6.1 indicating intrathecal synthesis; immunoglobulin M/G negative) labeling axonal fibers throughout the unfixed brain, particularly in cerebellum (figure, $\mathrm{C}$ ), corpus callosum, and hippocampus. The fine parallel fiber staining suggested binding to myelin epitopes (figure, C, insert). MOG antibodies were excluded (Prof. Höftberger, Vienna, Austria). Immunotherapy, including plasma exchange (10 sessions every other day) and rituximab (1,000 mg every 6 months for 2 years), resulted in the disappearance of MBP antibodies after 6 months and improvement of cognitive symptoms (Mini-Mental State Examination 16/ 30 ), which remained stable for 3 years until the last follow-up, antibodies remained negative.

To identify the antigen, immunoprecipitation and mass spectrometry were performed. One hundred micrograms of IgA purified from the plasma exchange eluate were incubated overnight

\footnotetext{
*These authors contributed equally to this work.
}

From the German Center for Neurodegenerative Diseases (DZNE) Berlin (H.S., N.K.W., J.K., H.P.); Institute of Integrative Neuroanatomy (M.H.), Charité-Universitätsmedizin Berlin; Medizinisches Proteom-Center (K.M., C.M.), Ruhr-University Bochum; Department of Neurology and Experimental Neurology (H.P.), Charite-Universitätsmedizin Berlin; and Center for Autoimmune Encephalitis and Paraneoplastic Neurological Syndromes (H.P.), Berlin, Germany.

Go to Neurology.org/NN for full disclosures. Funding information is provided at the end of the article.

The Article Processing Charge was funded by the authors.

This is an open access article distributed under the terms of the Creative Commons Attribution-NonCommercial-NoDerivatives License 4.0 (CC BY-NC-ND), which permits downloading and sharing the work provided it is properly cited. The work cannot be changed in any way or used commercially without permission from the journal. 

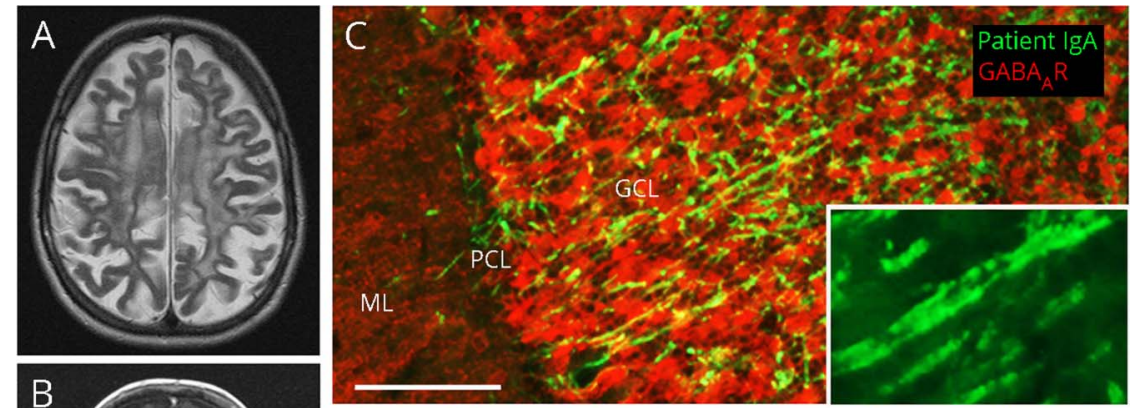
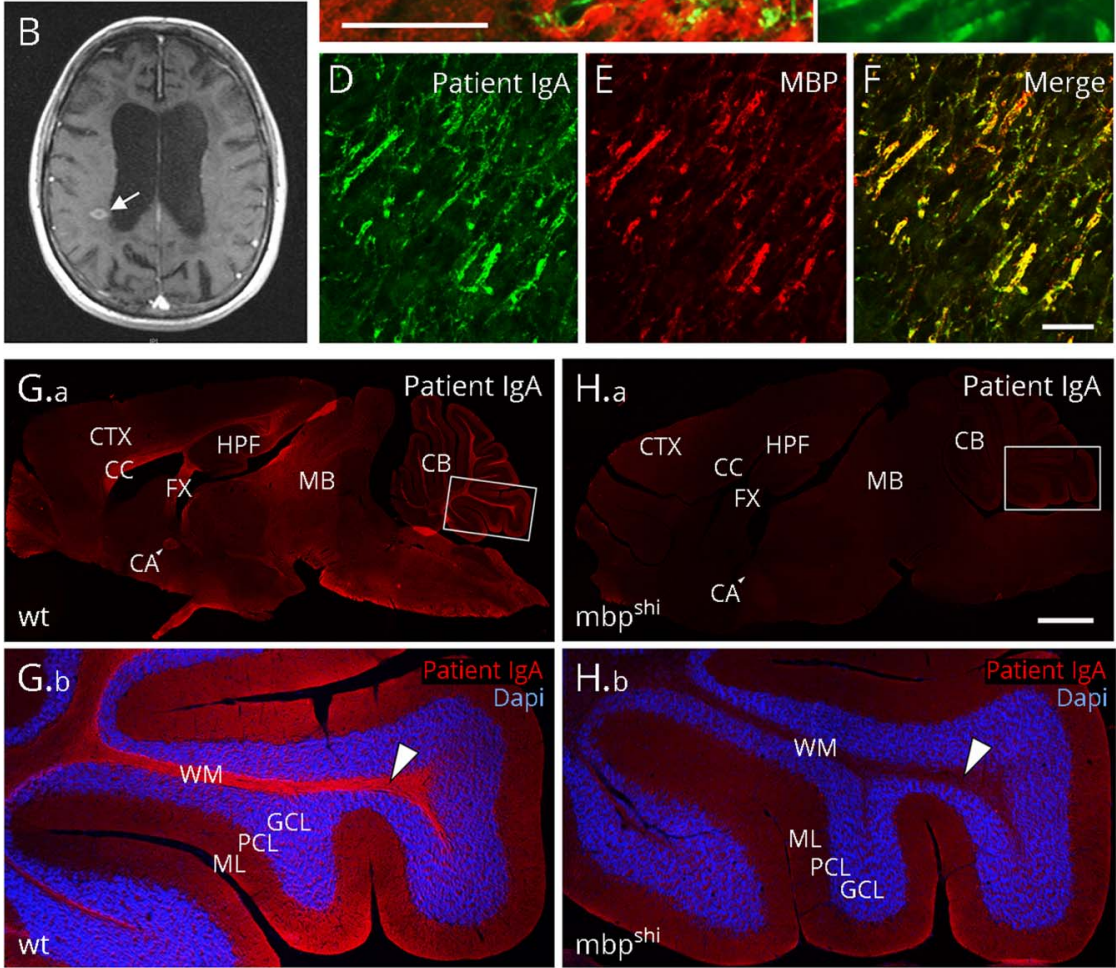

Patient IgA
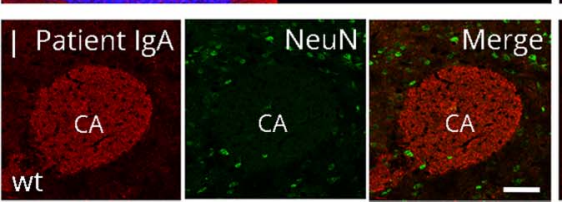

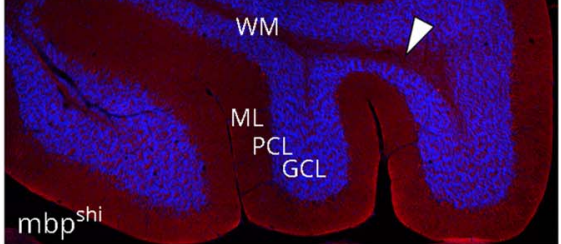

Patient

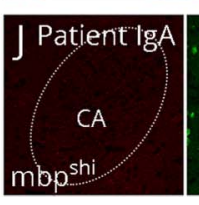

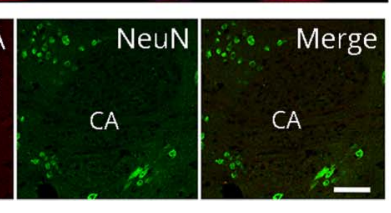

(A) Cerebral MRI shows atrophy, widespread postinflammatory changes and (B) new contrastenhancing lesions (arrow). (C) Using $20 \mu \mathrm{m}$ unfixed rat brain sections, patient IgA $(4.25 \mathrm{mg} / \mathrm{mL}$, dilution 1:10) labels fine axonal fibers (green, goat anti-human IgA, Dianova, Hamburg, Germany, dilution 1:200) throughout the brain, in particular in the cerebellar cortex (colabeling with a GABAA receptor antibody [red; Santa Cruz Biotechnology, Dallas, TX, USA, dilution 1:200] for better anatomical visualization of the cerebellar cortex). (C, inset) Higher magnification shows parallel staining of fibers, indicative of myelin antigens. (D-F) Double-labeling of patient IgA (green) with a commercial anti-MBP antibody [red, Santa Cruz Biotechnology, Dallas, TX, USA, dilution 1:200] demonstrates complete overlap in rat cerebellar cortex (merged in [F]). The characteristic immunofluorescence with strong binding to axonal fiber tracts on a $20 \mu \mathrm{m}$ paraformaldehyde-fixed mouse brain section ( $G$, red) was completely absent in shiverer MBP knockout (mbp ${ }^{\text {shi }}$ ) littermate mice $(\mathrm{H})$, exemplarily shown at higher magnification in the white matter of the cerebellum (arrowheads in G.b and H.b; double-labeling with DAPI for cell nuclei in blue) or the anterior commissure ( $\mathrm{l}, \mathrm{J}$; double-labeling with the neuronal marker NeuN in green). Bars represent $50 \mu \mathrm{m}$ in $\mathrm{C}-\mathrm{F}, 1 \mathrm{~mm}$ in $\mathrm{G}-\mathrm{H}$ and $50 \mu \mathrm{m}$ in I, J. CA = anterior commissure; $C B=$ cerebellum; $C \mathrm{C}=$ corpus callosum; $\mathrm{CTX}=$ cortex; FX = fornix; $\mathrm{GCL}=$ granule cell layer; $\mathrm{HPF}=$ hippocampal formation; $\mathrm{MB}=$ midbrain; $\mathrm{ML}=$ molecular layer; $\mathrm{PCL}=$ Purkinje cell layer; $\mathrm{WM}=$ white matter; and $w t=$ wild-type. with rat brain lysate and samples run on sodium dodecyl sulfate (SDS) gels. Bands were analyzed with mass spectrometry, ${ }^{5}$ and data were analyzed as described, ${ }^{6}$ matching MBP only. Double immunolabeling showed exact co-localization of patient antibody with a commercial anti-MBP antibody (figure, D-F). In contrast to the commercial antibody, the patient's IgA did not bind to rat brain lysate in denaturing Western blots (not shown), suggesting that they recognize the natural epitope conformation. Direct proof for the target antigen was obtained using MBP knockout mice in which the antibody binding was completely lost (figure, G-J).

\section{Discussion}

We report the case of a patient with MS with rapidly progressing cognitive decline having high-level autoantibodies against conformational MBP. Previous studies using denatured epitopes in enzyme-linked immunosorbent assay and Western blots could not establish a clear link between MBP antibodies and disease, ${ }^{2,3}$ potentially because they overlooked specific binding to the conformational epitope. This first report of MBP autoantibodies against native MBP revives the discussion of whether such antibodies might be related to a subgroup of MS patients, convey pathology, or serve as a biomarker for progression or cognitive symptoms.

Similar to MBP, the pathogenic role of MOG antibodies has been debated intensely. Only more recent studies focusing on antibody interactions with native MOG could convincingly demonstrate their pathogenic potential. ${ }^{7}$ For example, such MOG antibodies were present in a subgroup of patients with severe MS. 
The clinical improvement with immunotherapy in our patient paralleled the disappearance of antibody titers, suggesting that the antibodies may have contributed to the disease. IgA antibody transfer into animals should be an important future experimental step to confirm pathogenicity.

It is unclear at present whether autoantibodies against native MBP are also detected in a subgroup of patients with MS. We did not find a similar immunofluorescence pattern using the serum and CSF of 352 consecutive patients with suspected encephalitis (including 46 patients with MS) and serum of 82 healthy controls, suggesting that - similar to MOG antibodies-the specific myelin staining observed in the present patient is rare. Prospective studies using established cohorts with MS and clinically isolated syndrome (CIS) should therefore be screened systematically to determine the frequency of native MBPtargeting autoantibodies, the association with clinical phenotypes, CIS conversion to MS, relapses, and disease progression.

\section{Author contributions}

H. Schumacher: major role in the acquisition of data, analysis and interpretation of data, and drafting the manuscript. N.K. Wenke: acquisition of data. J. Kreye: acquisition of data. M. Höltje: acquisition of data. K. Marcus: acquisition of data. C. May: acquisition, analysis and interpretation of data, and critical revision of manuscript. H. Prüss: acquisition, analysis and interpretation of data, and critical revision of manuscript.

\section{Acknowledgment}

The authors are grateful to Professor Brian Popko, Department of Neurology, University of Chicago, for providing MBP knockout mouse brains.

\section{Study funding}

This work was supported by the HUPO Brain Proteome Project (HBPP) and PURE, a project of North RhineWestfalia, a federal German state.

\section{Disclosure}

The authors report no disclosures. Disclosures available: Neurology.org/NN.

\section{Publication history}

Received by Neurology: Neuroimmunology \& Neuroinflammation May 19, 2018. Accepted in final form March 14, 2019.

\section{References}

1. Olsson T, Baig S, Höjeberg B, Link H. Antimyelin basic protein and antimyelin antibodyproducing cells in multiple sclerosis. Ann Neurol 1990;27:132-136.

2. Berger T, Rubner P, Schautzer F, et al. Antimyelin antibodies as a predictor of clinically definite multiple sclerosis after a first demyelinating event. N Engl J Med 2003;349:139-145.

3. Kuhle J, Pohl C, Mehling M, et al. Lack of association between antimyelin antibodies and progression to multiple sclerosis. N Engl J Med 2007;356:371-378.

4. Pröbstel AK, Dornmair K, Bittner R, et al. Antibodies to MOG are transient in childhood acute disseminated encephalomyelitis. Neurology 2011;77:580-588.

5. Plum S, Helling S, Theiss C, et al. Combined enrichment of neuromelanin granules and synaptosomes from human substantia nigra pars compacta tissue for proteomic analysis. J Proteomics 2013;94:202-206.

6. Molina M, Steinbach S, Park YM, et al. Enrichment of single neurons and defined brain regions from human brain tissue samples for subsequent proteome analysis. J Neural Transm (Vienna) 2015;122:993-1005.

7. Reindl M, Rostasy K. MOG antibody-associated diseases. Neurol Neuroimmunol Neuroinflamm 2015;2:e60. doi: 10.1212/NXI.0000000000000060 


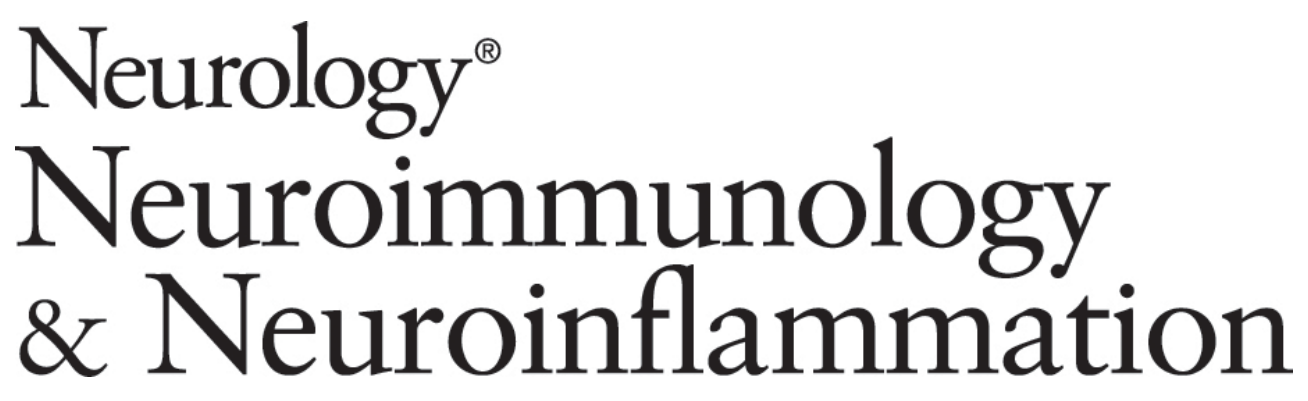

IgA autoantibodies against native myelin basic protein in a patient with MS Heike Schumacher, Nina K. Wenke, Jakob Kreye, et al.

Neurol Neuroimmunol Neuroinflamm 2019;6;

DOI 10.1212/NXI.0000000000000569

This information is current as of May 1, 2019

Neurol Neuroimmunol Neuroinflamm is an official journal of the American Academy of Neurology.

Published since April 2014, it is an open-access, online-only, continuous publication journal. Copyright

Copyright $\odot 2019$ The Author(s). Published by Wolters Kluwer Health, Inc. on behalf of the American

Academy of Neurology.. All rights reserved. Online ISSN: 2332-7812.

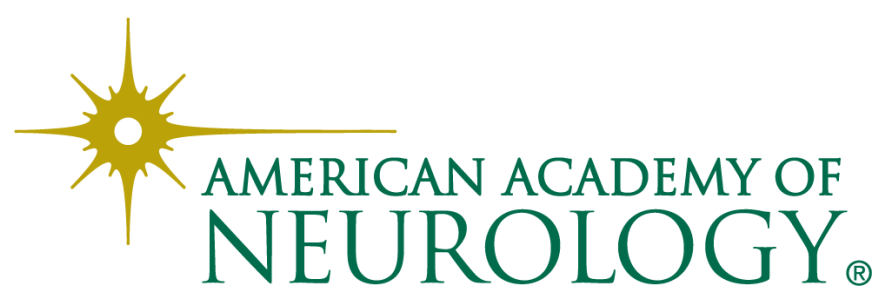




\section{Updated Information \& Services}

References

Subspecialty Collections

Permissions \& Licensing

Reprints including high resolution figures, can be found at:

http://nn.neurology.org/content/6/4/e569.full.html

This article cites 7 articles, 0 of which you can access for free at: http://nn.neurology.org/content/6/4/e569.full.html\#\#ref-list-1

This article, along with others on similar topics, appears in the following collection(s):

\section{All Cognitive Disorders/Dementia}

http://nn.neurology.org//cgi/collection/all_cognitive_disorders_dementi a

All Demyelinating disease (CNS)

http://nn.neurology.org//cgi/collection/all_demyelinating_disease_cns All Immunology

http://nn.neurology.org//cgi/collection/all_immunology

Autoimmune diseases

http://nn.neurology.org//cgi/collection/autoimmune_diseases

Multiple sclerosis

http://nn.neurology.org//cgi/collection/multiple_sclerosis

Information about reproducing this article in parts (figures,tables) or in its entirety can be found online at:

http://nn.neurology.org/misc/about.xhtml\#permissions

Information about ordering reprints can be found online:

http://nn.neurology.org/misc/addir.xhtml\#reprintsus

Neurol Neuroimmunol Neuroinflamm is an official journal of the American Academy of Neurology.

Published since April 2014, it is an open-access, online-only, continuous publication journal. Copyright

Copyright $\left({ }^{\circ} 2019\right.$ The Author(s). Published by Wolters Kluwer Health, Inc. on behalf of the American

Academy of Neurology.. All rights reserved. Online ISSN: 2332-7812.

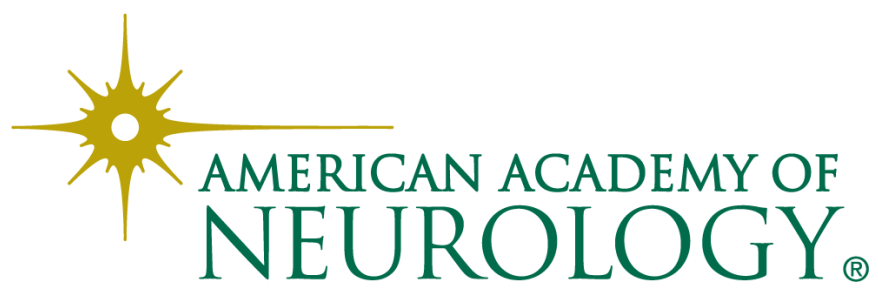

